\title{
Literal approach to translation: a classification and literature review
}

\author{
Anzhelika O. Lomaka
}

\section{DOI: 10.18355/XL.2017.10.04.19}

\begin{abstract}
This paper studies the two approaches to translation which have been the subject of debate for a long time - the literal approach and the free approach. It presents the theoretical and conceptual framework of literal translation by illuminating the studies of a number of researchers with different attitudes to this phenomenon. The paper shows that there is no consensus among researchers on whether literal translation or free translation should be considered primarily an approach to translation. The study also analyzes the notion of literalism and distinguishes between the main types of literalisms (etymological, semantic, lexical and grammatical) by illustrating examples. The paper uses general scientific methods such as observation, analysis and synthesis, as well as descriptive, classification, generalization and selection methods. The author proves that literalism often causes the distortion of meaning and violates the norms of the target language. Therefore, the translator should carefully select equivalents to prevent the artificiality of translation.
\end{abstract}

Key words: literalism, literal translation, free translation, target language, source language

\section{Introduction}

When translating into the target language, the translator should be able to carefully search for such equivalents for the elements of the original text that will ensure an adequate translation, i.e. will create together a secondary text whose content will fully correspond to the communicative task. According to Guy (2011), the main task of the translator is "to bring a new kind of reading of the given work from a semantic and a stylistic point of view", which will make it possible for the reader "to seize the closest version possible to the one that the author intended to present". One aspect of the adequacy of translation is the avoidance of literalism.

Kallenbach (2016) believes that avoiding literalisms is the most difficult part of being a translator: "It requires employing many different skills simultaneously: reading comprehension, writing proficiency, language knowledge and more. It requires a translator to extract the meaning from the source language, while at the same time escaping its stylistic-linguistic influence".

An important fact is that the majority of novice translators resort to literal translation in one way or another. This serves as a practical confirmation of the hypothesis put forward by Latyshev (2005) that the translator performs the transformation of literal translation, which, albeit in an implicit form, at the initial stage of the translation process is present in the translator's mind.

Literal translation implies the transfer of communicatively irrelevant elements of the source text, which may result in a violation of the semantic component of the target text or a shift in semantic emphasis. At the same time, speaking of literalisms, Kallenbach (2016) does not mean a text translated word for word. He argues that there is a more subtle issue: "a translation which is technically "correct"-definitely not "Google translate" - but still closely emulates the form, order, and linguistic idiosyncrasies of its source".

Currently, the degree of the proximity of translation to the source text, the permissibility of literal or free translation, the need to preserve the same effect on the reader, etc., are the subject of extensive discussion. There is no consensus among researchers on whether literal translation or free translation should be considered 
primarily an approach to translation. Some translators put accuracy above all, incurring accusations of literalism, violation of the norms of the target language and propaganda of the "translation language", others, advocating creative and free translation, sometimes deviate far from the source text and are subjected to criticism for "translation arbitrariness" and distortion of the original.

Although the subject of literal translation vs free translation turned out to be extremely developed for translation studies and there are a great number of factual studies, which give an idea of different translation practices, their evolution, typical mistakes, etc., a detailed study of translation errors is recognized as relevant for the development of criteria and methodology of translation quality evaluation both in the process of translation training and at the level of its implementation as the final product of professional translation activities.

Therefore, the purpose of this study is to present a theoretical framework of supporters and opponents of literal translation, to define the notion of literalism and to distinguish between the main types of literalisms by illustrating examples.

For scientific interpretation of factual materials, such general scientific methods as observation (of linguistic material), analysis and synthesis (to justify theoretical statements) were used.

The study also applied a descriptive method (to interpret the notion of literalism), a method of classification and generalization (to determine the basic types of literalism) and a method of selection, which consisted in the selection of literalism examples and their translations into Ukrainian.

\section{Literature Review}

The opposition 'literal translation vs free translation' has gained wide popularity, and persistent disputes among advocates of both approaches to translation (especially of the literary text) continue to occur. At the same time, supporters of literal translation consider the correspondence of translation to the spirit of the native language and the habits of the domestic reader to be important, while opponents of literal translation insist that it is more important to accustom the reader to perceive a different way of thinking, a different culture.

According to Chironova (2014), the application of the literal approach to translation may lead to either satisfactory or unsatisfactory results, thus "adequate translations or translations violating target text rules may appear".

In the late 20th century, L. Venuti (2008) in his work The Translator's Invisibility: A History of Translation defined translation strategies as "foreignization" (approximation of the target text to the source text at the expense of the beauty and power of the target language) and "domestication" (subordination of the translation text to the norms and traditions existing in the target language at the expense of the source text). It should be emphasized that modern masters of translation mostly adhere to the "domestication" style of translation. However, the other translation strategy still has its supporters.

\subsection{Opponents of Literal Translation}

Literal translation is regarded as the closest possible rendering of a foreign language text into another language. According to Ordudari (2007), literal translation is such a translation in which "the source language grammatical constructions are converted to their nearest translation language equivalents, but the lexical words are again translated singly, out of context".

Back in the ancient world, translators discussed the degree of the proximity of translation to the source text. In the early translations of the Bible, the literal copying of the original text prevailed (Alekseev, 1999). The Church defended the literal

XLinguae, Volume 10, Issue 4, October 2017, ISSN 1337-8384, eISSN 2453-711X 
approach to translation, because wanted to exclude any possibility of an ambiguous or not quite correct understanding of the text. Such literal copying of the original text sometimes led to the misunderstanding of translation, which, of course, was a significant drawback that significantly reduced the quality of translation (Garusova, 2007).

Due to this situation, after a while, translators tried to theoretically substantiate the translator's right to greater freedom with respect to the original, the need to reproduce not the letter, but the meaning or even the overall impression of the text (Parshin, 1995). In the best case scenario, the literal approach to translation was regarded as a "pre-translation process" (Newmark, 1988: 11).

Cicero believed that literalism is a sign of the translator's weakness, his language poverty. In translation, he urged to convey not the form, but the meaning, while focusing on a "specific recipient", in accordance with the laws of the target language. For this purpose, it was necessary to translate not individual words, but try to convey their "strength and impression" (Semenets, Panasiev, 1989).

Pushkin emphasized the inadmissibility of literal translation based on the examples of the translation of Milton's poems into French: "There is no doubt that in attempting to render Milton word for word Chateaubriand could not in his version preserve accurately both the meaning and the idiomatic turns of phrase. A literal translation can never be true to its original. Every language has its own locutions, its accepted rhetorical figures, its assimilated expressions which cannot be translated into another language simply by using the corresponding words" (Wolf, 1986: 460).

The literal approach to translation has been criticized by researchers for a long time. Low (2003) believes that they mostly have been right: "The worst examples of this approach look like the work of novices with poor dictionaries and untenable views about "literal translation" producing maximum accuracy".

Linguistic substantiation for literal translation was provided by Barkhudarov (1969): "Literal translation is a translation performed at a lower level than that which is sufficient to transfer an unchanged content plan while respecting the norms of the target language" (p. 10).

Nida (1964) applied the notion of "absurd literalism". Speaking of an attempt of some "misguided persons" to put out a so-called Concordant version in English by translating the Greek or Hebrew terms by the same English word, he argued: "The results are lamentable, for the attempt to be literal in the form of the message has resulted in grievous distortions of the message itself".

Following Nida's opinion on the inappropriateness of literalisms in translation, Wonderly (1966) speculated: "Literal translations, especially between linguistically and culturally diverse languages, tend to overload the decoder's channel; therefore a translation needs to be "drawn out" longer by building in redundancy, both linguistic and cultural, if it is to communicate satisfactorily (p. 810).

Opponents of literal translation believe that it cannot often convey the meaning of the original text. According to Blake (2003), sometimes words "cannot be literally translated from one language to another, owing to a lack of clear correspondence between the words of the two languages". Cultural phraseological units, context or meaning can be lost in the process of literal translation. Koptilov (1973) also stressed that the text should be translated 'not from sound to sound, not from word to word, not from phrase to phrase', but from the element of the ideological-figurative structure of the source language to the appropriate level of the target language.

Bond, Baldwin, Fothergill and Uchimoto (2012), describing the creation of the Japanese SemCor (JSEMCOR), a translation of the English SEMCOR, pointed out the phenomenon of literalism as one of the main difficulties in translation. They concluded that literal translation is unnatural in many cases: "either there is a lexical gap in Japanese so that the English term does not have any translation, or the direct translation has a different connotation". 
Mkrtchyan (1987) described literalism as "the most boring interlocutor". He wrote that when he had to edit and compile translated books, in disputed cases he always preferred a translation that was well read and badly compared to the original text.

As can be seen, a number of researchers believe that literal translation is an inadequate approach to translation, and literalisms are translation errors, which often lead to the distortion of meaning.

\subsection{Supporters of Literal Translation}

In modern translation studies, a literal translation of linguistic phenomena is seen as a specific technique used by translators to achieve a certain pragmatic effect and implemented within the framework of the "transitive strategy" (Kokunova, 2012). The transitive strategy is consistently implemented at all levels of the translated text: most proper names are rendered in transcription or transliteration; the translator, as a rule, attempts to find the nearest direct semantic correspondence to the lexicon of the source text in the target language; linguocultural and semasiological lacunae are not filled; tropes (figures of speech), phraseological units, syntactic structures are very often rendered literally. The result of the implementation of such a strategy is translations accurately and fully conveying the formal specifics of the source text, however, their perception by the reader is hampered by a large number of dark implicates, lacunae, loanwords and literalisms perceived as 'discomfortives' (Tretyakova, 2006: 454)

Tretyakova (2006) considers literalism not as a translation error, but as a translation technique, a loan translation to which the translator resorts when discovers a gap in one of his translation competences: linguistic, speech, linguocultural, ethnocultural, cross-cultural, etc.

Supporters of literal translation defend the idea that if the translator creates a text with words different from the original, i.e. "adjusts" a translation to the system of the target language, it cannot be called a translation at all.

In particular, German humanist and translator Nicholas von Vilem (XV century) proved himself a supporter of literal translation, defending the idea that each word in the source language should be replaced by the same word in the target language. In this way, he translated the works of Petrarch, Boccaccio, Apuleius. Despite this controversial theoretical approach, Vilem made a significant contribution to the transformation of Middle High German, which had not been fully developed, into literary language, by enriching it with some grammatical and syntactical devices and techniques from Latin and Italian (Koptilov, 2002).

Discussing the basis of literalism and the pragmatic need for its survival, Shen (1989) claims that literalism is "word translation plus syntax transplantation, imposing source language's peculiar syntax on translation language words, treating translation language as a syntactically unpatterned system".

Speaking of literalism supporters, we could not but mention V.V. Nabokov, whose theoretical position is usually attributed to the tradition of so-called translational literalism, but this point of view needs to be clarified.

Despite the fact that Nabokov's position is characterized by a distinct tendency to the maximum restriction of freedom of the translator as an intermediary between the author of the original and the readership, he recognized literal translation meaningless in its generally known sense (as a formal replacement of the source language elements without drawing attention to their figurative system). Nabokov's theory is based on the principle of semantic equivalence at the expense of the most accurate reproduction of associative and syntactic features of the source language.

According to Nabokov (1990), literal translation means "rendering, as closely as the associative and syntactical capacities of another language allow, the exact contextual meaning of the original. Only this is true translation" (p. 27).

XLinguae, Volume 10, Issue 4, October 2017, ISSN 1337-8384, eISSN 2453-711X 
Vyazemsky, Fet and Bryusov were also among those who supported the idea that translation should be a copy of the original (Ratgauz, 1996). For example, Vyazemsky wrote that there are two ways to translate: independent and subordinate. Following the former, the translator, "filled with the meaning and spirit of the original, pours them into his forms". Following the latter, the translator "attempts to preserve the very forms, comprehending, of course, the lines of the language that he has at hand" (Ratgauz, 1996).

Having analyzed the opposition 'literal translation vs free translation', we can conclude that the very issue of literal and free translations, considered from antiquity to our days, is still a relevant and interesting research subject in foreign and domestic translation studies.

\section{Brief Introduction of the Notion of Literal Translation}

Literal translation is understood as a kind of translation that characterizes the way of rendering the source text and the approach to achieving equivalence, which suggests that all elements of the source text are reproduced one by one without regard to their position and possible changes of their meaning in the context, to the detriment of their communicative significance, which often leads to the distortion of all levels of the text. For example, the inappropriateness of literal translation can be seen in the following example: "George said that the same kind of thing, only worse, had happened to him some eighteen months ago ..." (Jerome, 2001: 103). A common mistake is the literal translation of the phrase "eighteen months" as "вісімнадиять місяиів". The way of expressing "eighteen months" is natural for native English speakers, i.e. it is a certain reality. The same natural way for native Ukrainian speakers is the use of a numeral "півтора", і.е. "півтора року". Therefore, such a translation by substitution is considered appropriate.

However, in some cases, it is possible to use literal translation, ensured by the presence of monosemantic words, grammatical forms, syntactic combinations and the same established ways of expressing phenomena in the source and target languages, e.g.:

Who wrote this letter? - Хто написав цей лист?

Who took my pen? - Хто взяв мою ручку?

I live in Ukraine. - Я живу в Украӥні.

These examples demonstrate the same way of expressing a situation. It is clear that such an unambiguous interpretation of the source language elements is possible not in all sentences, therefore, the translator must be protected from the temptation to use literalisms, in order to prevent the artificiality of translation.

According to the definition given by Komissarov (2011), literal translation is a translation that reproduces communicatively irrelevant elements of the source text, which results in the violation of the norms and usage of the target language or the distortion of the content of the source text.

In the context of literal translation, the possibility of using various kinds of substitutions and transformations is excluded, since the technique of such a translation presupposes the word-for-word reproduction of all units of the source language statement, which are often put in the same order in the target text as they were in the source text.

An attempt to reproduce semantic elements of a higher equivalence level, without ensuring that the content is rendered at previous levels, also leads to literal translation, e.g.: "Let sleeping dogs lie" is literally translated as "Не буди сплячого собаку". However, the literal translation of this statement describes a completely different situation and does not correspond to the communicative task, which implies that one should not interfere in a situation that is currently causing no problems but may well do so as a result of such interference (i.e. "Не чіпай лихо, доки воно тихо"). 
The concept of literal translation is often considered in connection with the problem of a translation unit. Retsker (2004) argues that literalism arises from the incorrect selection of such a unit as a correspondence to the original unit.

It is believed that literal translation is performed by the translator word for word at the level of morphemes and word for word at the level of vocabulary, i.e. literally under the influence of the native or foreign language (Alimov, 2017). Therefore, there are two main types of literalism: etymological, associated with the origin of the word, and semantic, associated with its meaning.

\section{Classification of Literalisms}

\subsection{Etymological Literalisms}

Etymological literalism, a more primitive type of novice translators, consists in using the externally similar word or phrase, which in its meaning does not correspond to the original word or phrase.

It is possible to present a long list of foreign words having "etymological" correspondences in Ukrainian, which in reality turn out to be imaginary. Such words, similar in spelling or sound, are usually called "false friends of a translator". These words are very often interferents (interfering) and their use leads to lexical or semantic interference (Table 1).

Table 1. Examples of etymological literalisms in translation from English to Ukrainian

\begin{tabular}{|l|l|l|}
\hline \multicolumn{1}{|c|}{ Word } & \multicolumn{1}{c|}{ Literalism } & \multicolumn{1}{c|}{ Adequate translation } \\
\hline magazine & магазин & журнал \\
\hline complexion & $\begin{array}{l}\text { будова тіла, } \\
\text { комплекція }\end{array}$ & колір обличчя \\
\hline decade & декада & десять років \\
\hline lunatic & лунатик & божевільний \\
\hline activities & активність & діяльність \\
\hline genial & геніальний & добрий \\
\hline repetition & репетиція & повторення \\
\hline intelligent & інтелігентний & розумний, кмітливий \\
\hline Dutch & датський & голландський \\
\hline рatron & патрон & начальник, хазяїн, покровитель \\
\hline bucket & букет & відро \\
\hline fabric & фабрика & фабрикат, тканина, текстура \\
\hline list & $\begin{array}{l}\text { лист рослини, аркуии } \\
\text { паперу }\end{array}$ & перелік \\
\hline mоdе & мода & $\begin{array}{l}\text { метод, спосіб; тех. } \text { і комп. режим; } \\
\text { муз. лад }\end{array}$ \\
\hline
\end{tabular}

Etymological literalisms can also include phrases, e.g. "formal accusation" (charge) literally means "формальне звинувачення", but it should be translated as "офіиійне звинувачення". When translating some terms from Ukrainian into English, there are also some lexical difficulties, e.g.: "трансформатор" should be translated as "transformer", not "transformator", "водяний підігрівач" - "boiler", not "water heater", "батарея" - "radiator", not "battery".

Thus, the translator should always check the meaning of "false friends" in terminology dictionaries and keep in mind true internationalisms, which acquire a certain qualitative specificity in professional texts. They can create new phrases and

XLinguae, Volume 10, Issue 4, October 2017, ISSN 1337-8384, eISSN 2453-711X 
often require translation equivalents, which are sometimes absent in dictionaries. This leads to difficulties in translation. Therefore, it is necessary to take into account this specificity and avoid translation errors.

\subsection{Semantic Literalisms}

This type of literalism is more complicated than etymological, and consists in using the general, most known, as a rule, meaning of the word or word combination instead of the concrete or contextual meaning. It also includes the translation of phraseological units based on individual meanings of their components. For example, as Retsker notes (2004), "Hear! Hear!” does not mean "Слухайme! Слухайme!” (lit. "Listen! Listen!”), but it expresses a strong approval: "Правильно! Правильно!" (lit. "Right! Right!"). Although this meaning was fixed in a number of dictionaries, even experienced translators are mistaken in translating this repetition.

Consider some examples where an inexperienced translator, without taking into account the context, applies literal translation instead of adequate. In the sentence "Вона була обрана делегатом республіканського з"їду" ("She was elected a delegate to the National Convention") the word 'республіканський should be translated as 'national', because it means загальнонаціональний, while the word 'republican' may mean the Republican Party Convention to the English reader.

Another example is as follows: when we are talking about відрахування якоїсь суми громей, a mathematical operation віднімання ('deduction from') comes to mind. But what about an expression 'відрахування в пенсійний фонд’? Deduction means 'відрахування з чогось', not 'до чогось'. Here the translator should be guided by the logic of action rather than direct loan translation, thus instead of the word 'deduction' one should use the word 'contribution to' (i.e. додавання not віднімання).

Some examples of semantic literalism are presented in Table 2.

Table 2. Examples of semantic literalisms in translation from English to Ukrainian

\begin{tabular}{|l|l|l|}
\hline \multicolumn{1}{|c|}{ Word } & General meaning & \multicolumn{1}{c|}{ Сoncrete meaning } \\
\hline man & людина & чоловік, солдат, робітник \\
\hline house & дім & житло, приміщення, будівля \\
\hline speculation & спекуляція & розміркування, припущення \\
\hline communication & комунікація & зв'язок, відносини, спілкування \\
\hline value & цінність & значення, ціна \\
\hline effect & ефект & вплив, враження, результат, наслідок \\
\hline character & характер & персонаж, літера \\
\hline nature & природа & властивість, сутність \\
\hline resource & ресурс & відпочинок, можливість, джерело \\
\hline actor & актор & дійова особа, діяч, учасник \\
\hline
\end{tabular}

Sometimes a literal translation of some word combinations may sound rather ridiculous: to call a spade a spade - називати лопату лопатою (instead of "називати речі своїми іменами"), hungry as a hunter - голодний як мисливець (instead of “голодний як вовк"). The phraseological unit 'to call names' is translated as "сварити" not "називати імена", 'to bring home to' - "переконувати". The proverb "It is long lane that has no turning" does not mean "Шлях без кривих довгий" (a straight path seem longer than it is), but "перемелеться - борошно буде". The phrase "We are in the same boat" (“ми в однаковому становищіџ") was translated once as "Ми в одному човні". In the latter case, the translator did not realize that it was an idiomatic unity. 
Literalism of machine translation and inexperienced translators is often the subject of jokes. Take, for example, the following classic phrase, which can cause difficulties even for those who have a good command of English: "Mother Her, She is ill". It would seem obvious and incredibly funny in Ukrainian - "Мати ï̈, вона хвора". However, with all the nuances of the English language, this phrase should be translated as "Оточи ї̈ турботою, вона хвора".

Kayumova (2011) gives the following example of semantic literalism. The sentence "Wherever there was a table with a committee of ladies sitting round it in council there was Mr. Godfrey at the bottom of the board, keeping the temper of the committee, and leading the dear creatures along the thorny ways of business, hat in hand." was translated into Russian as "Где только дамский комитет, там и мистер Годфри с иляпой в руке сдерживает горячность собрания и ведет мильх дам по тернистому деловому пути."

Here the phraseological unit 'hat in hand', meaning 'obediently' ('покорно'), was literally translated 'с иляпой в руке'. The translator was subjected to the "hypnosis of the word", i.e. extracted the meaning of the whole from the meanings of the components (Kayumova, 2011).

Thus, semantic literalism makes it difficult to understand the meaning, and in many cases violates the norms of the target language.

\subsection{Lexical and Grammatical Literalisms}

Literalisms can also be of the following types: lexical and grammatical. Here are a few examples of lexical literalisms: Kill goose that lays golden eggs - Вбити гусака, щзо несе золоті яйця (instead of “Вбити курку, щзо несе золоті яйця"); So many men, so many minds - Скільки людей, стільки й розумів (instead of "Скільки голів, стільки й розумів"); Look not a gift horse in the mouth - Дарованому коневі не дивися в рот (instead of "Дарованому коневі в зуби не дивляться", "В зуби не заглядають, зубів не лічать” оr “Дар - не купля: не гудять, а хвалять”).

Grammatical literalism is considered a mistake due to the establishment of false connections at the grammatical level. An example can be so-called absolute constructions like "Do not walk with his eyes down" - Він йшов з очима, опущеними в землю (instead of “Він йшов, опустивши очі"). Another example presents a discrepancy in the word order: "If you run after two hares, you will catch neither" - "Поженешся за двома зайчями, не впіймаєш жодного" (instead of "Не женись за двома зайиями - жодного не спіймаєш"). The phrase “в інтернеті" sometimes is literally translated as "in the Internet" instead of the English equivalent "on the Internet", which violates the norms of the target language.

\section{Conclusions}

The theoretical analysis shows that literal translation is often considered inadequate. It should be noted that the classification of free and literal translation is the most traditional and, at the same time, narrow approach to understanding the translation error. This approach indicates the violation of only one translation norm - the equivalence rate, and on the other hand - neither assesses the quality of translation to a full extent nor gives an idea of the degree of the misleading effect of translation. However, many novice translators make a number of mistakes in translation precisely due to the inappropriate use of literalisms. Therefore, it is very important to draw attention to the possibility of literal translation and to prevent the artificiality of translation.

The examples given prove that any type of literalism in translation, including etymological and semantic, can equally cause the distortion of meaning or violate the norms of the target language. They also demonstrate that literalism often leads to the

XLinguae, Volume 10, Issue 4, October 2017, ISSN 1337-8384, eISSN 2453-711X 
loss of aesthetic qualities of the text and the improper transmission of the content, i.e. to the distortion of the idea in the target text. That is why we believe that the selection of lexical-semantic equivalents with regard to their contextual links and the pragmatic-communicative aspect of the source statement is the basis of an adequate and accurate translation.

Literal translation can be applied only in cases when the translator has a pragmatic super-task to reproduce the formal features of constructing the statement in the source language. However, in such cases, literal translation can be accompanied by explanations or an adequate translation, revealing the true content of the original.

\section{Bibliographic references}

ALEKSEEV, A.A. 1999. Tekstologiya slavyanskoy Biblii [Textology of the Slavonic Bible]. St. Petersburg: Dmitrii Bulanin. ISBN 5-86007-114-0; ISBN 3-4I2-00598-3.

ALIMOV, V.V. 2017. Teoriya perevoda. Perevod v sfere professional'noy kommunikatsii [Translation theory. Translation in the field of professional communication] (6th ed.). Moscow: Lenand. ISBN 978-5-9710-4500-7.

BARKHUDAROV, L.S. 1969. Urovni yazykovoy iyerarkhii i perevod [Levels of the language hierarchy and translation]. In: Tetradi Perevodchika, 6, 10.

BLAKE, C. 2003. Ethical considerations in working with culturally diverse populations: The essential role of professional interpreters. In: Bulletin of the Canadian Psychiatric Association, 21-23. ISSN 1708-0622.

BOND, F. - BALDWIN, T. - FOTHERGILL, R. - UCHIMOTO, K. 2012. Japanese SemCor: A Sense-tagged Corpus of Japanese. In: Proceedings of the 6th International Global Wordnet Conference (GWC 2012), Matsue, Japan. ISBN 978-80-263-0244-5.

CHIRONOVA, I.I. 2014. Literalism in translation: Evil to be avoided or unavoidable reality? In: SKASE Journal of Translation and Interpretation, 7(1), 28-40. ISSN 13367811.

GARUSOVA, E.V. 2007. "Bukvalizm” i “vol'nost"” kak osnovnaya perevodcheskaya oppozitsiya ["Literal translation" and "free translation" as a basic translation opposition]. In: Proceedings of Voronezh State University (Series: Linguistics and Intercultural Communication), 1, 149-153. ISSN 1680-5755.

GUY, N. 2011. Difficultés de traduction d'un roman slovaque contemporain vers le français: l'exemple de English is easy, Csaba is dead de Peter Doktorov. In: XLinugae, 2, 13-17. ISSN 1337-8384.

JEROME, J.K. 2001 [1889]. Three men in a boat (to say nothing of the dog). P. Luciana (Ed.). Florence-Milan: Giuntu. ISBN 9788809753228.

KALLENBACH, A. 2016. The greatest challenge facing translators. Available online: http://aclang.com/en/2855-2/

KAYUMOVA, A.R. 2011. Perevod frazeologicheskikh yedinits: tipologiya oshibok [Translation of phraseological units: typology of errors]. Paper presented at the International Philological Conference, Section XL: Lexicology and Phraseology (Romano-Germanic Cycle), 14-19 March, St. Petersburg State University, St. Petersburg (pp. 73-76). ISBN 978-5-8465-1213-9. Available online: http://kpfu.ru/staff_files/F22566220/Spb.Tipologiya.oshibok.pdf

KOKUNOVA, Yu.V. 2012. Bukvalizmy v perevodakh khudozhestvennykh fil'mov: prichiny i sledstviya [Literality in feature films translation: Causes and consequences]. In: Perevod i Sopostavitel'naya Lingvistika, 8, 24-28. ISSN: 2304-215X.

KOMISSAROV, V.N. 2011. Sovremennoye perevodovedeniye [Modern translation studies]. Moscow: R. Valent. ISBN 978-5-93439-312-1.

KOPTILOV, V.I. 1973. I vshir' i vglub' [Broad and deep]. In: K.N. Polonskaya (Ed.), Masterstvo perevoda [Mastery of translation] (Vol.9, pp. 257-261). Moscow: Sovetskiy Pisatel.

KOPTILOV, V.V. 2002. Teoriya i praktyka perekladu [Theory and practice of translation]. Kyiv: Yunivers. ISBN 966-7305-65-1. 
LATYSHEV, L.K. 2005. Tekhnologiya perevoda [Technology of translation] [Textbook] (2nd ed.). Moscow: Akademiya. ISBN 5-89191-022-5; ISBN 5-76952020-5.

LOW, P. (2003). Translating poetic songs: An attempt at a functional account of strategies. In: Target, 15(1), 91-110. ISSN 0924-1884; E-ISSN 1569-9986.

MKRTCHYAN, L.M. 1987. Yesli by v Vavilone byli perevodchiki [If there were translators in Babylon]. Yerevan: Sovetakan Grokh.

NABOKOV, V. [1964] 1990. Eugene Onegin. A translation from the Russian of Aleksandr Pushkin's (1833) Yevgeniy Onegin. Princeton: Princeton University Press. ISBN: 9780691019048.

NEWMARK, P. 1988. A textbook of translation. New York: Prentice Hall. ISBN-10: 0139125930; ISBN-13: 978-0139125935.

NIDA, E. A. 1964. Toward a science of translating, with special reference to principles and procedures involved in Bible translating. Leiden: Brill. ISBN-10: 9004026053; ISBN-13: 978-9004026056

ORDUDARI, M. 2007. Translation procedures, strategies and methods. In: Translation Journal, 11(3). ISSN 1536-7207. Available online: http://translationjournal.net/journal/41 culture.htm

PARSHIN, A.N. 1995. Teoriya i praktika perevoda [Theory and practice of translation]. Moscow: Vysshaya Shkola. Available online: http://teneta.rinet.ru/rus/pe/parshin-and_teoria-i-praktika-perevoda.htm

RATGAUZ, G. 1996. O perevodakh Borisa Pasternaka [On translations of Boris Pasternak]. In: Inostrannaya Literatura, 12. ISSN 0130-6545. Available online: http://magazines.russ.ru/inostran/1996/12/radgauz.html

RETSKER, Ya.I. 2004. Teoriya perevoda i perevodcheskaya praktika. Ocherki lingvisticheskoy teorii perevoda [Translation theory and translation practice. Essays on the linguistic theory of translation]. Moscow: R. Valent. ISBN 5934391321; 9785934391325 .

SEMENETS, O.E. - PANASIEV, A.N. 1989. Istoriya perevoda [History of translation] [Textbook]. Kyiv: Izdatel'stvo pri Kiyevskom Universitete. ISBN 5-11000418-8.

SHEN, D. 1989. Literalism: Non "formal-equivalence". In: Babel, 35(4), 219-235. ISSN 0521-9744; E-ISSN 1569-9668.

TRETYAKOVA, E.A. 2006. Sravnitel'nyy analiz perevodcheskikh strategiy peredachi fol'klornomifologicheskikh implitsitnykh smyslov $\mathrm{v}$ khudozhestvennom tekste [Comparative analysis of translation strategies to render folklore and mythological implicit meanings in an artistic text]. Paper presented at the 8th Jubilee International Scientific Conference on Translation Studies "Fedorov's Readings" Dedicated to the 100th Anniversary of the Birth of A.V. Fedorov, 19-21 October, St. Petersburg State University, St. Petersburg (University Translation Studies, 8, pp. 453-458).

VENUTI, L. 2008. The translator's invisibility: A history of translation (2nd ed.). London \& New York: Routledge. ISBN-10: 0415394554; ISBN-13: 978-0415394550. WOLF, T. (Ed.). 1986. Pushkin on literature. (T. Wolff, Trans.). Stanford: Stanford University Press. ISBN 0810116154; 9780810116153.

WONDERLY, W.L. 1966. Toward a science of translating, with special reference to principles and procedures involved in Bible translating [Review of the book Toward a science of translating, with special reference to principles and procedures involved in Bible translating, by E. A. Nida]. In: American Anthropologist, 68, 808-810. ISSN 1548-1433.

XLinguae, Volume 10, Issue 4, October 2017, ISSN 1337-8384, eISSN 2453-711X 
Words: 5249

Characters: 35784 (19,9 standard pages)

Anzhelika Oleksandrivna Lomaka

Department of Germanic and Romance Philology and Translation

Volodymyr Dahl East Ukrainian National University

93406, Severodonetsk (Luhansk), 41 Donetska St.

Ukraine

anglomaka@gmail.com 